Article

\title{
Preparation and Characteristics of $\mathrm{MAPbBr}_{3}$ Perovskite Quantum Dots on $\mathrm{NiO}_{x}$ Film and Application for High Transparent Solar Cells
}

\author{
Lung-Chien Chen ${ }^{1, *(\mathbb{D})}$, Kuan-Lin Lee ${ }^{1}$, Chun-Yuan Huang ${ }^{2}{ }^{\mathbb{D}}$, Jia-Ching Lin ${ }^{1}$ \\ and Zong-Liang Tseng ${ }^{1}$ \\ 1 Department of Electro-Optical Engineering, National Taipei University of Technology, Taipei 10608, Taiwan; \\ zw144@yahoo.com.tw (K.-L.L.); t104658082@ntut.edu.tw (J.-C.L.); tw78787788@yahoo.com.tw (Z.-L.T.) \\ 2 Department of Applied Science, National Taitung University, Taitung 95092, Taiwan; laputa@nttu.edu.tw \\ * Correspondence: ocean@ntut.edu.tw; Tel.: +886-2-2771-2171
}

Received: 12 April 2018; Accepted: 26 April 2018; Published: 27 April 2018

\begin{abstract}
In this work, a $\mathrm{MAPbBr}_{3}$ quantum dot (QD-MAPbBr 3$)$ layer was prepared by a simple and rapid method. Octylammonium bromide $(\mathrm{OABr})$ gives the $\mathrm{MAPbBr}_{3}$ better exciton binding energy, good surface morphology, and stability. To form a nanocrystalline thin film on indium tin oxide (ITO) glass, the QD-MAPbBr 3 film was coated by a spin-coating method in a nitrogen-filled glove box and the $\mathrm{NiO}_{\mathrm{x}}$ film was used as an adhesive layer and hole transport layer. The highest transmittance of $\mathrm{MAPbBr}_{3}$ on $\mathrm{NiO}_{x} / \mathrm{ITO}$ glass was around $75 \%$ at $700 \mathrm{~nm}$. This study also reported a high transparent and perovskite bulk-free $\mathrm{ITO} / \mathrm{NiO}_{\mathrm{x}} / \mathrm{QD}-\mathrm{MAPbBr}_{3} / \mathrm{C}_{60} / \mathrm{Ag}$ solar cell where the $\mathrm{NiO}_{x}, \mathrm{QD}-\mathrm{MAPbBr}_{3}$, and $\mathrm{C}_{60}$ were used as a hole transport layer, active layer, and electron transport layer, respectively.
\end{abstract}

Keywords: $\mathrm{MAPbBr}_{3}$ perovskite; transparent solar cells; $\mathrm{NiO}_{\mathrm{x}}$; quantum dots

\section{Introduction}

The power conversion efficiency of perovskite solar cells has increased from $3.8 \%$ in 2009 to $22.1 \%$ in several years [1-7]; improvements in the efficiency of these solar cells have thus been remarkably rapid. Perovskite cells are also more cost effective than silicon cells and are easy to fabricate. Perovskites generally have an $\mathrm{ABX}_{3}$ structure $(\mathrm{A}=$ cationic organic molecule; $\mathrm{X}=$ halide) $[8,9]$. These materials have a number of unique attributes including bipolarity, high absorption coefficients, long carrier diffusion lengths, and high solar conversion efficiencies [10-12]. Furthermore, the sources of perovskite components are relatively abundant. A number of studies have been conducted on perovskite quantum dots. For example, Im et al. proposed a QD-MAPbI ${ }_{3}$ solar cell [13], and Huang et al., developed a QD-MAPbI ${ }_{3}$ light-emitting diode [14]. The perovskite material used in this experiment was QD-MAPbBr 3 . When compared to crystal $\mathrm{MAPbBr}_{3}$ films, QD-MAPbBr 3 has unique physicochemical characteristics such as tunable band gaps, a functionalizable surface, and high quantum yields [15]. However, QD-MAPbBr 3 has poor surface morphologies; these traits can be expected to affect the efficiencies of the solar element. Recent studies have shown that reductions in the sizes of perovskite crystals effectively reduce the number of internal defects in the perovskite material and the probability of non-radiative transitions. This was shown to improve the fluorescence efficiency of the QD-MAPbBr 3 material as well as its stability $[16,17]$. Several articles about colloidal QD solar cells have been reported [18-20], however, in our work comprising the perovskite QDs $\left(\mathrm{MAPbI}_{3}\right)$, the colloidal QDs (ZnSe) demonstrated poor reliability, as shown in Figure 1. Even so, QD-MAPbBr 3 is still far away from commercial applications. In this work, octylammonium bromide $(\mathrm{OABr})$ was added to $\mathrm{QD}-\mathrm{MAPBr}_{3}$ to 
improve its exciton binding energies, surface morphology, and stability to improve the efficiency of QD-MAPBr 3 devices.

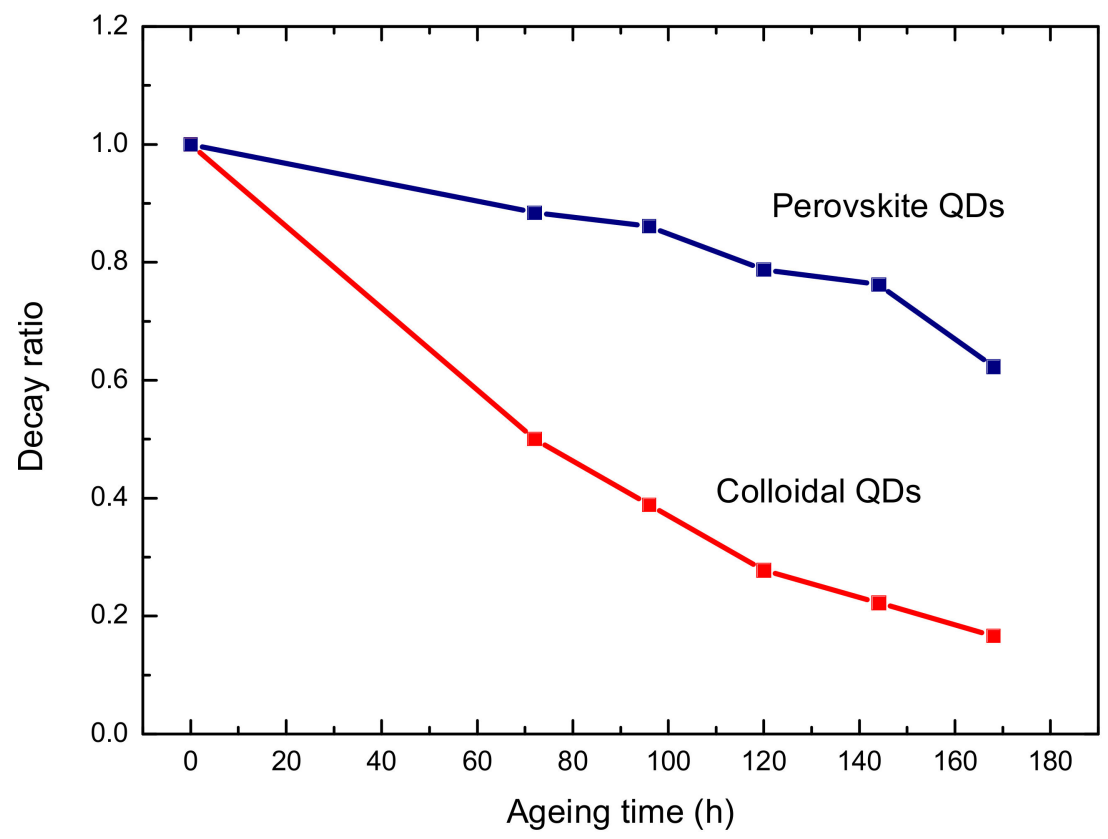

Figure 1. Ageing test of perovskite and colloidal of quantum dots (QDs) using photoluminescence.

\section{Materials and Methods}

First, a $\mathrm{MAPbBr}_{3}$ perovskite quantum dot solution was prepared. $\mathrm{OABr}$ powder $(37.8 \mathrm{mg})$ was added to a solution containing $6 \mathrm{~mL}$ of octadecene and $60 \mu \mathrm{L}$ of oleic acid. A methylammonium bromide (MAB) solution (13.2 mg of MAB dissolved in $300 \mu \mathrm{L}$ of dimethylformamide (DMF) solvent) and $\mathrm{PbBr}_{2}$ solution (110.1 mg of $\mathrm{PbBr}_{2}$ dissolved in $500 \mu \mathrm{L}$ of DMF solvent) were then added to this mixture to form the $\mathrm{MAPbBr}_{3}$ precursor solution (with 30, 120, 240, or $360 \mathrm{~min}$ of reaction time), as shown in Figure 2. Acetone was then added, followed by centrifugation to isolate the yellow precipitate from the $\mathrm{MAPbBr}_{3}$ precursor solution. The yellow precipitates were then dried under vacuum for half a day to completely remove the solvents of the precursor solution. The $\mathrm{MAPbBr}_{3}$ powder was then dissolved in hexane to prepare the $\mathrm{MAPbBr}_{3}$ perovskite quantum dot solution. The detail of the QD-MAPbBr 3 process has been reported elsewhere [21].
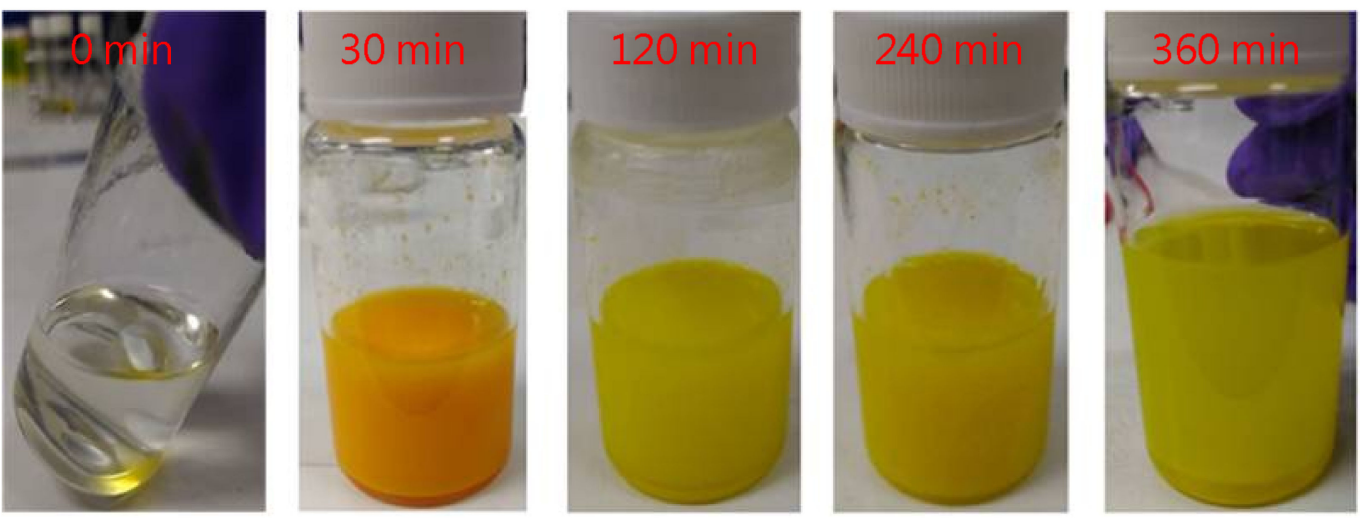

Figure 2. Pictures of $\mathrm{QD}-\mathrm{MAPbBr} 3$ solutions for different reaction times. 
The ITO glass substrate was sonicated for $10 \mathrm{~min}$ in acetone, and then in ethanol, and finally isopropanol. A nitrogen gun was used to dry the substrate, which was irradiated in UV-ozone for $10 \mathrm{~min}$. A $0.45-\mu \mathrm{m}$ syringe filter was used to drop $\mathrm{NiO}_{x}$ evenly on the ITO substrate, followed by spin coating at $4500 \mathrm{rpm}$ for $90 \mathrm{~s}$. The substrate was then heated at $120^{\circ} \mathrm{C}$ on a hot plate for $10 \mathrm{~min}$, and baked in an oven at $350{ }^{\circ} \mathrm{C}$ for $10 \mathrm{~min}$. The $\mathrm{NiO}_{\mathrm{x}}$ film here was as an adhesive layer and hole transport layer to coat the $\mathrm{QD}-\mathrm{MAPbBr}_{3}$ layer. The resulting $\mathrm{NiO}_{\mathrm{x}} / \mathrm{ITO}$ substrate was placed in a glove box filled with nitrogen, and a micropipette was used to evenly drop $50 \mu \mathrm{L}$ of QD-MAPbBr 3 on the $\mathrm{NiO}_{x} /$ ITO substrate. The substrate was then coated in two stages (the rotational speeds and times of the first and second stages were $1000 \mathrm{rpm}$ for $10 \mathrm{~s}$ and $3000 \mathrm{rpm}$ for $10 \mathrm{~s}$, respectively). After the coating process was completed, the substrate was placed on a hot plate for heating at $80^{\circ} \mathrm{C}$ for five minutes. Finally, $\mathrm{C}_{60}$ and $\mathrm{Ag}$ were then thermally deposited one after the other in a thermal evaporator with a high-vacuum environment $\left(1.5 \times 10^{-6}\right.$ torr $)$ to complete the whole cell structure. In this device, $\mathrm{NiO}_{x}$ was the hole transport layer, $\mathrm{QD}-\mathrm{MAPbBr}_{3}$ was the absorption layer, and $\mathrm{C}_{60}$ was the electron transport layer. The current density-voltage (J-V) curves of the photovoltaic cells were obtained using a source-measurement unit (2400, Keithly, Cleveland, OH, USA). The optical intensity of the simulated sunlight was calibrated using a reference cell (91150V, Oriel, Strarford, CT, USA) with an optical filter (KG-5) to have an intensity of $100 \mathrm{~mW} / \mathrm{cm}^{2}$. The absorbance spectra were determined by a visible spectrometer. The crystallinities of $\mathrm{MAPbBr}_{3}$ thin films were determined by a commercial X-ray diffractometer (PW-1830, PANalytical, Almelo, The Netherlands). The photoluminescence (PL) spectra were measured with a commercial PL spectrometer (Protrustech Co., Ltd., Taipei, Taiwan).

\section{Results and Discussion}

Figure 3a shows a scanning electron microscopy (SEM, GeminiSEM, ZEISS, Oberkochen, Germany) image of the surface morphology of the QD-MAPbBr 3 film with 30 min of reaction time. Here, it presented significant differences in the size between the grains of the film, and some of these grains were aggregated into QD-MAPbBr 3 particles. This could be because the reaction time allowed for the reaction between $\mathrm{PbBr}_{2}$ and the mixture of $\mathrm{MAB}$ and medium-chain OABR in the presence of oleic acid and octadecene was insufficiently short in this case, thus the reactions at each grain were still incomplete. Figure $3 \mathrm{~b}$ exhibits the smallest and most homogeneous grains among the four reaction times. The QD-MAPbBr 3 particles that covered the $\mathrm{NiO}_{x}$ layer were smooth and uniform and formed a continue film. This indicated that $120 \mathrm{~min}$ of reaction time was the optimal reaction time. However, as the reaction time increased to $240 \mathrm{~min}$, the $\mathrm{OABr}$ precipitated on the surface, causing some of the grains to aggregate into a sheet-like film, as shown in Figure 3c. When the reaction time was increased to $360 \mathrm{~min}$, the surface morphology was a continued film due to the grain aggregation of most of the QDs by the formation of a homogeneous solution, as shown in Figure 3d. Figure 4a presents a transmission electron microscopy (TEM, Tecnai F30, Philips, Germany) image of the QD-MAPbBr 3 particle consisting of many quantum dots. The sizes of the quantum dots ranged between $5 \mathrm{~nm}$ and $7 \mathrm{~nm}$, as shown in Figure 4b. The QD-MAPbBr 3 particle formed from many $\mathrm{MAPbBr}_{3}$ quantum dots due to aggregation. However, there was no reaction between the quantum dots.

Figure 5 shows the XRD patterns of the QD-MAPbBr ${ }_{3}$ films. The QD-MAPbBr ${ }_{3}$ films were deposited on the $\mathrm{NiO}_{\mathrm{x}}$ layer for all measurements in this study. The diffraction peaks occurred at $14.53^{\circ}, 22.04^{\circ}, 29.7^{\circ}, 33.5^{\circ}$, and $45.35^{\circ}$, and these reflections corresponded to the (100), (110), (200), and (300) crystal lattice planes of the $\mathrm{MAPbBr}_{3}$, respectively [22,23]. After annealing, XRD peaks of the $\mathrm{MAPbBr}_{3}$ films were slightly shifted towards higher diffraction angles. Two diffraction peaks with the most intensities at $14.53^{\circ}$ and $29.7^{\circ}$ were significantly increased after the annealing process. This indicated that the annealed film had smaller crystal lattice distances and greater crystallinity than that of the film without annealing treatment. 


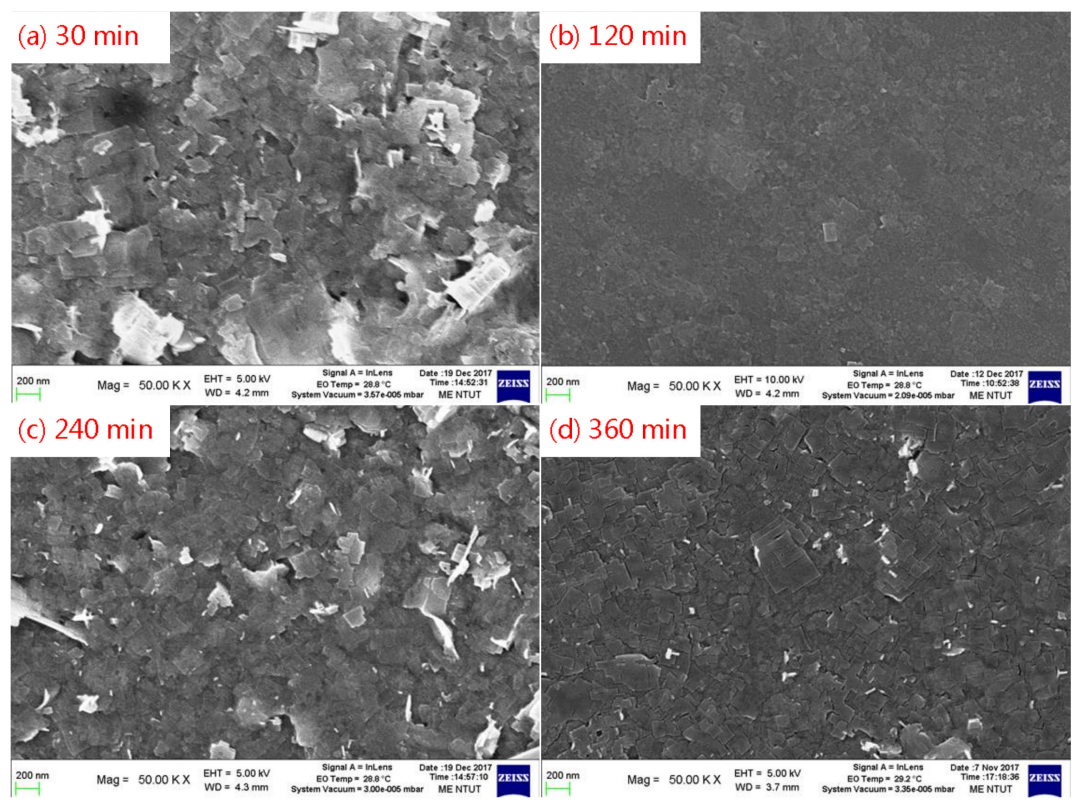

Figure 3. SEM images of the surface morphologies of the QD-MAPbBr 3 films for the reaction times of (a) 30; (b) 120; (c) 240; and (d) $360 \mathrm{~min}$.

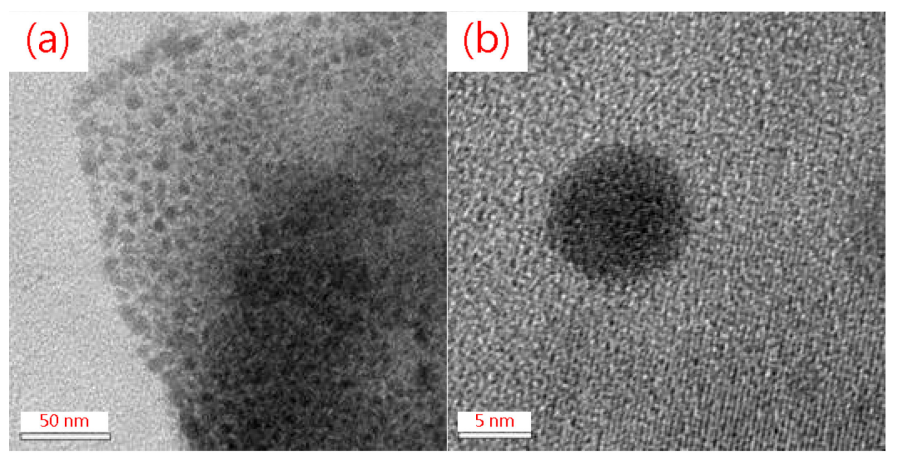

Figure 4. TEM images of the QD-MAPbBr 3 (a) particle and (b) quantum dot.

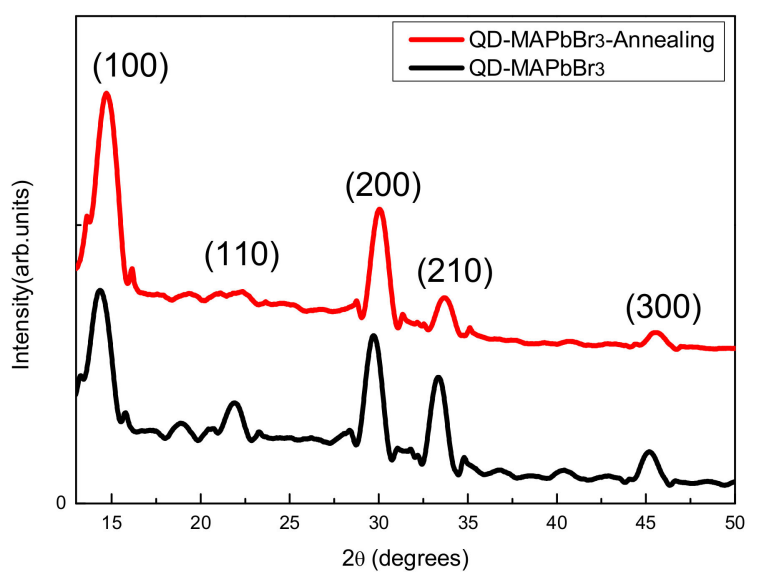

Figure 5. XRD patterns of the QD-MAPbBr 3 with and without annealing treatment.

Figure 6 shows the photoluminescence (PL) spectra of $\mathrm{QD}-\mathrm{MAPbBr}_{3}$; the locations of peaks of the QD-MAPbBr 3 solution, the film without annealing, and the annealed film were at 539, 531, and $533 \mathrm{~nm}$, 
respectively. The band gap can be expected to increase when the size of the quantum dots becomes smaller, thus leading to a blue shift of the PL emission peak. In this work, the PL spectrum of the film without annealing exhibited a greater blue shift than that of the film with annealing. This indicated that the film without annealing had a smaller particle size and larger band gap than the film with annealing. The inset is a picture of a QD-MAPbBr 3 specimen that emitted green light while being excited by a 405-nm laser. The fluorescence quantum yield is around $4.96 \%$. It reveals a high trap density in the QD-MAPbBr layer [24-27]. Figure 7 shows the absorption spectra of the QD-MAPbBr 3 films. One may observe that the films absorbed significantly between $400 \mathrm{~nm}$ and $500 \mathrm{~nm}$, and the absorption increased slightly after film annealing. When compared to conventional $\mathrm{MAPbBr}_{3}$ films, the absorption peak of the QD-MAPbBr ${ }_{3}$ films underwent a blue shift to $491 \mathrm{~nm}$ due to the quantum confinement effects in $\mathrm{MAPbBr}_{3}$ [28]. Figure 8 shows the transmittance spectra of QD-MAPbBr 3 with and without annealing. The transmittance of the film was $65 \%$ between $600 \mathrm{~nm}$ and $1000 \mathrm{~nm}$, but only $10 \%$ between $400 \mathrm{~nm}$ and $500 \mathrm{~nm}$. The highest transmittance was around $75 \%$ at $700 \mathrm{~nm}$ in the spectrum of QD-MAPbBr 3 on $\mathrm{NiO}_{x} / \mathrm{ITO}$ glass. The location of the absorption edge was at $500 \mathrm{~nm}$, corresponding to the absorption of the QD-MAPbBr 3 films. The inset in Figure 8 is an image of the $\mathrm{QD}-\mathrm{MAPbBr}_{3}$ film and shows that the text below the film was easily readable.

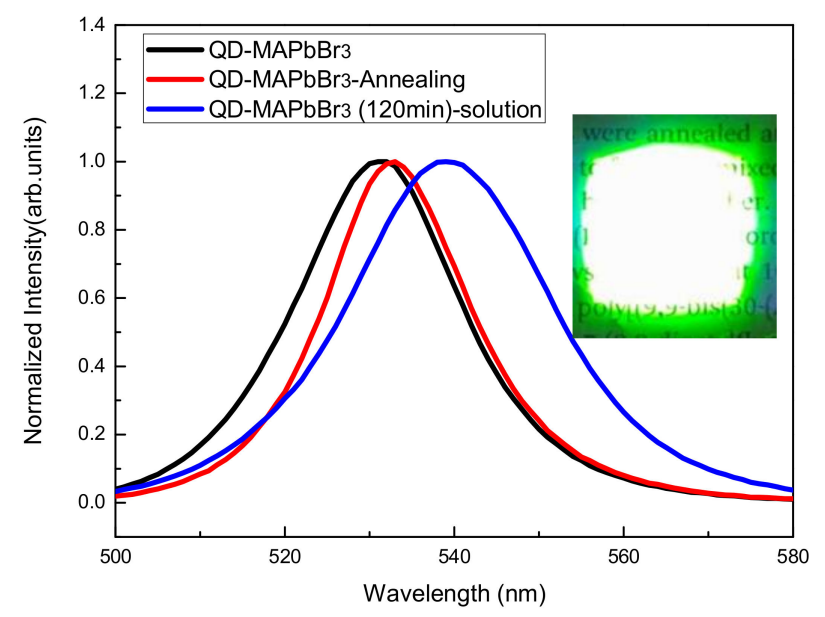

Figure 6. PL spectra of the QD-MAPbBr 3 films with and without annealing treatment. The inset shows a picture of the QD-MAPbBr 3 film excited by a $405-\mathrm{nm}$ laser.

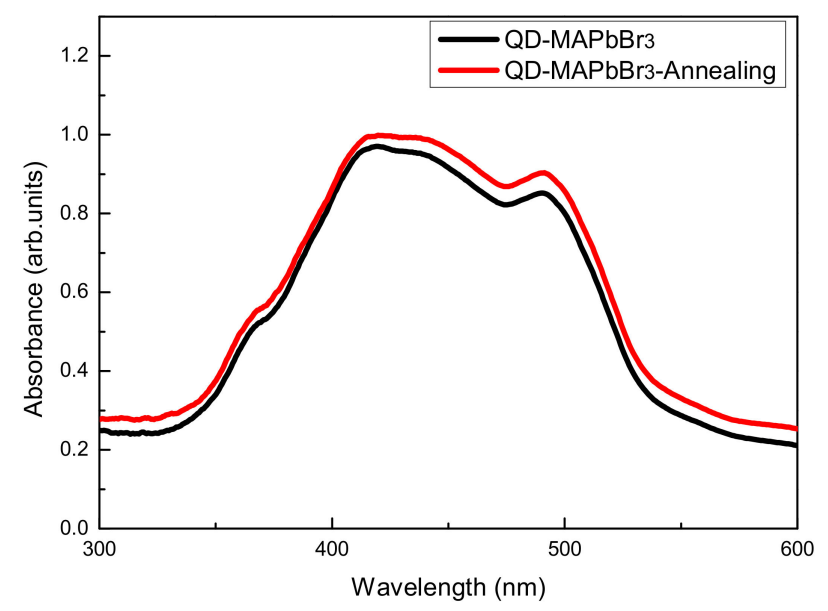

Figure 7. Absorption spectra of the QD-MAPbBr 3 films with and without annealing treatment. 


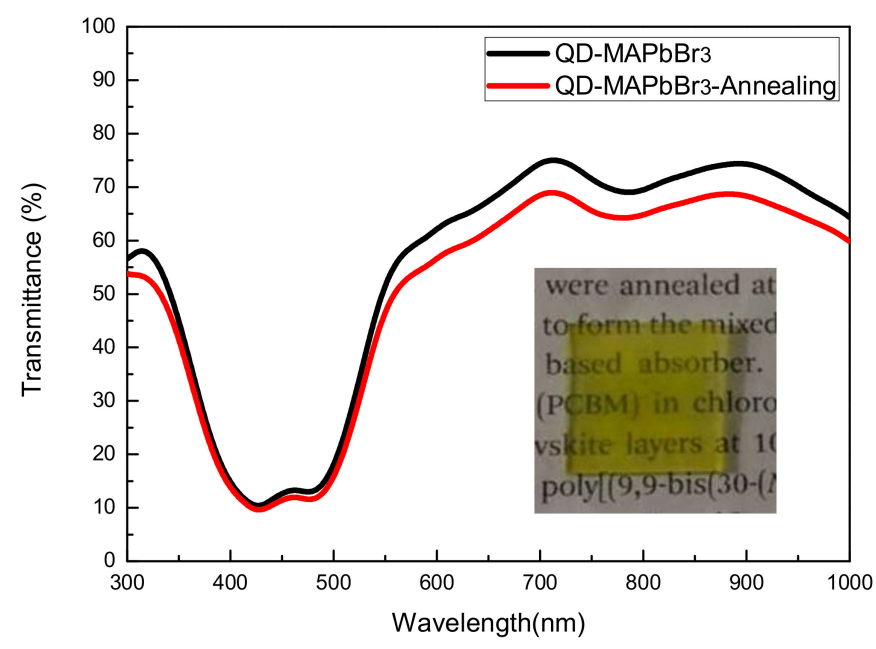

Figure 8. Transmittance spectra of the $\mathrm{QD}-\mathrm{MAPbBr}_{3}$ films with and without annealing treatment. The inset shows the picture of the QD-MAPbBr 3 film.

Figure 9 illustrates the structure of a QD-MAPbBr 3 solar cell device. Figure 10 presents a typical $\mathrm{J}-\mathrm{V}$ curve of the ITO/NiO/QD-MAPbBr $3 / \mathrm{C}_{60} / \mathrm{Ag}$ structure solar cell. The open circuit voltage $\left(\mathrm{V}_{\mathrm{oc}}\right)$, current density $\left(\mathrm{J}_{\mathrm{sc}}\right)$, fill factor $(\mathrm{FF})$, and power conversion efficiency $(\mathrm{PCE}, \%)$ of the solar cell were $0.04 \mathrm{~V}, 0.257 \mathrm{~mA} / \mathrm{cm}^{2}, 0.258$, and 0.0347 , respectively. The QD-MAPbBr 3 solar cell exhibited poor performance due to the high resistance of the QD-MAPbBr ${ }_{3}$ film. This may have contributed to the electron transition in the QD-MAPbBr 3 film being hard from quantum dot to quantum dot, from grain to grain, and from particle to particle, as shown in Figures 3 and 4.

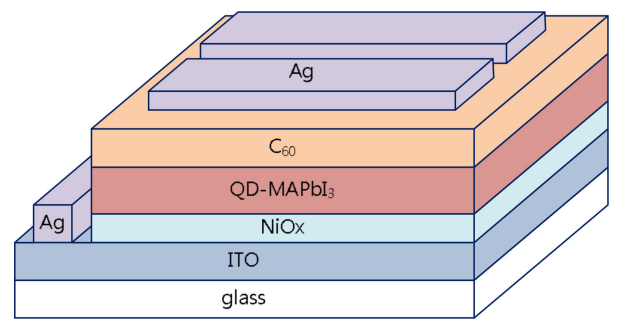

Figure 9. Structural diagram of the QD-MAPbBr 3 solar cell.

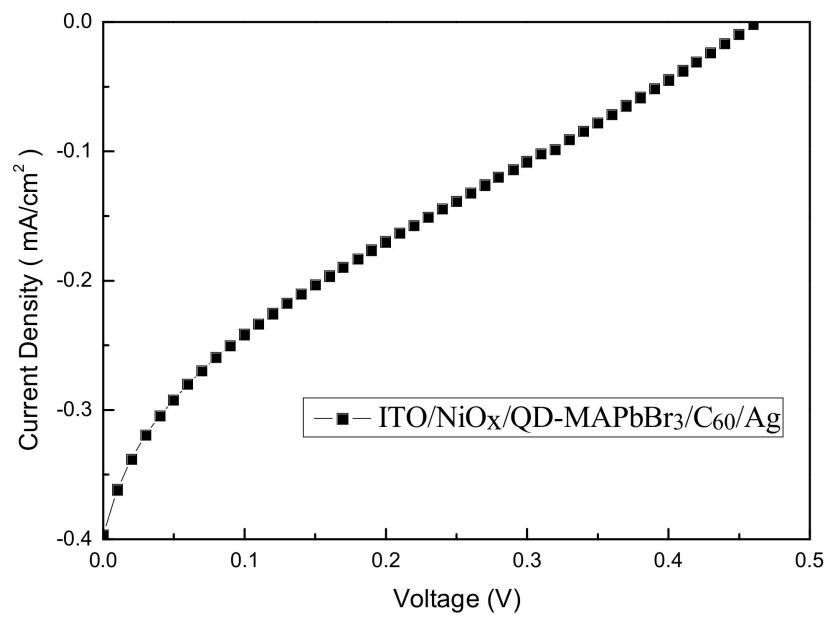

Figure 10. Typical J-V curve of the ITO/NiO/QD-MAPbBr $3 / \mathrm{C}_{60} / \mathrm{Ag}$ structure solar cell. 


\section{Conclusions}

This work involved varying the reaction time of the reaction between $\mathrm{MAB}, \mathrm{PbBr}_{2}$, and $\mathrm{OABr}$ to optimize the size of the precipitating particles of the resulting $\mathrm{QD}-\mathrm{MAPbBr}_{3}$ solution; this solution was then spin-coated to form a film and was used as the active layer of a perovskite solar cell. The transmittance spectra showed that the $\mathrm{QD}-\mathrm{MAPbBr}_{3}$ films had high levels of transmissivity, and their PL spectra also indicated a significant degree of fluorescence. The TEM image showed that these films consisted of nanocrystals with a size of approximately $6 \mathrm{~nm}$. However, the J-V curve and PCE values of the film showed that the FF of the resulting solar cell was poor. The QD-MAPbBr 3 solar cell exhibited a high transparency, but poor performance. Electron transition in the QD-MAPbBr 3 film was hard from quantum dot to quantum dot, from grain to grain, and from particle to particle. Therefore, the QD-MAPbBr 3 film requires further refinement to improve its quality, as the maximum solar conversion efficiency of the film is only $0.0347 \%$ at present.

Author Contributions: L.-C.C. wrote the paper, designed the experiments, and analyzed the data. K.-L.L., C.-Y.H., J.-C.L., and Z.-L.T. prepared the samples and performed all measurements. All authors read and approved the final manuscript.

Acknowledgments: This work was supported by the Ministry of Science and Technology under Grant MOST 106-2221-E-027-091.

Conflicts of Interest: The authors declare no conflict of interest.

\section{References}

1. Kuang, C.; Tang, G.; Jiu, T.; Yang, H.; Liu, H.; Li, B.; Luo, W.; Li, X.; Zhang, W.; Lu, F.; et al. Highly efficient electron transport obtained by doping PCBM with graphdiyne in planar-heterojunction perovskite solar cells. Nano Lett. 2015, 15, 2756-2762. [CrossRef] [PubMed]

2. Gong, X.; Li, M.; Shi, X.-B.; Ma, H.; Wang, Z.-K.; Liao, L.-S. Controllable Perovskite Crystallization by Water Additive for High-Performance Solar Cells. Adv. Funct. Mater. 2015, 25, 6671-6678. [CrossRef]

3. Li, Y.; Sun, W.; Yan, W.; Ye, S.; Peng, H.; Liu, Z.; Bian, Z.; Huang, C. High-Performance Planar Solar Cells Based On $\mathrm{CH}_{3} \mathrm{NH}_{3} \mathrm{PbI}_{3-x} \mathrm{Cl}_{x}$ Perovskites with Determined Chlorine Mole Fraction. Adv. Funct. Mater. 2015, 25, 4867-4873. [CrossRef]

4. You, J.; Meng, L.; Song, T.-B.; Guo, T.-F.; Yang, Y.M.; Chang, W.-H.; Hong, Z.; Chen, H.; Zhou, H.; Chen, Q.; et al. Improved air stability of perovskite solar cells via solution-processed metal oxide transport layers. Nat. Nanotechnol. 2015, 11, 75-81. [CrossRef] [PubMed]

5. Burschka, J.; Pellet, N.; Moon, S.-J.; Humphry-Baker, R.; Gao, P.; Nazeeruddin, M.K.; Grätzel, M. Sequential deposition as a route to high-performance perovskite-sensitized solar cells. Nature 2013, 499, 316-319. [CrossRef] [PubMed]

6. Jeon, N.J.; Noh, J.H.; Kim, Y.C.; Yang, W.S.; Ryu, S.; Seok, S.I. Solvent engineering for high-performance inorganic-organic hybrid perovskite solar cells. Nat. Mater. 2014, 13, 897-903. [CrossRef] [PubMed]

7. Jeon, N.J.; Noh, J.H.; Yang, W.S.; Kim, Y.C.; Ryu, S.; Seo, J.; Seok, S.I. Compositional engineering of perovskite materials for high-performance solar cells. Nature 2015, 517, 476-480. [CrossRef] [PubMed]

8. Cheng, Z.; Lin, J. Layered organic-inorganic hybrid perovskites: Structure, optical properties, film preparation, patterning and templating engineering. CrystEngComm 2010, 12, 2646-2662. [CrossRef]

9. Mosconi, E.; Amat, A.; Nazeeruddin, M.K.; Grätzel, M.; De Angelis, F. First principles modeling of mixed halide organometal perovskites for photovoltaic applications. J. Phys. Chem. C 2013, 117, 13902-13913.

10. Heo, J.H.; Im, S.H.; Noh, J.H.; Mandal, T.N.; Lim, C.-S.; Chang, J.A.; Lee, Y.H.; Kim, H.-J.; Sarkar, A.; Nazeeruddin, M.K.; et al. Efficient inorganic-organic hybrid heterojunction solar cells containing perovskite compound and polymeric hole conductors. Nat. Photonics 2013, 7, 486-491. [CrossRef]

11. Stranks, S.D.; Eperon, G.E.; Grancini, G.; Menelaou, C.; Alcocer, M.J.P.; Leijtens, T.; Herz, L.M.; Petrozza, A.; Snaith, H.J. Electron_hole diffusion lengths exceeding 1 micrometer in an organometal trihalide perovskite absorber. Science 2013, 342, 341-344. [CrossRef] [PubMed] 
12. Xing, G.; Mathews, N.; Sun, S.; Lim, S.S.; Lam, Y.M.; Grätzel, M.; Mhaisalkar, S.; Sum, T.C. Long-range balanced electron- and hole-transport lengths inorganic-inorganic CH3NH3PbI3. Science 2013, 342, 344-347. [CrossRef] [PubMed]

13. Im, J.H.; Lee, C.R.; Lee, J.W.; Park, S.W.; Park, N.G. 6.5\% efficient perovskite quantum-dot-sensitized solar cell. Nanoscale 2011, 3, 4088-4093. [CrossRef] [PubMed]

14. Huang, H.L.; Zhao, F.C.; Liu, L.G.; Zhang, F.; Wu, X.G.; Shi, L.J.; Zou, B.S.; Pei, Q.B.; Zhong, H.Z. Emulsion Synthesis of Size-Tunable $\mathrm{CH}_{3} \mathrm{NH}_{3} \mathrm{PbBr}_{3}$ Quantum Dots: An Alternative Route toward Efficient Light-Emitting Diodes. ACS Appl. Mater. Interfaces 2015, 7, 28128-28133. [CrossRef] [PubMed]

15. Zhang, F.; Zhong, H.; Chen, C.; Wu, X.-G.; Hu, X.; Huang, H.; Han, J.; Zou, B.; Dong, Y. Brightly Luminescent and Color-Tunable Colloidal $\mathrm{CH}_{3} \mathrm{NH}_{3} \mathrm{PbX}_{3}(\mathrm{X}=\mathrm{Br}, \mathrm{I}, \mathrm{Cl})$ Quantum Dots: Potential Alternatives for Display Technology. ACS Nano 2015, 9, 4533-4542. [CrossRef] [PubMed]

16. Schmidt, L.C.; Pertegás, A.; González-Carrero, S.; Malinkiewicz, O.; Agouram, S.; Espallargas, G.M.H.; Bolink, J.; Galian, R.E.; Pérez-Prieto, J. Nontemplate Synthesis of CH3NH3PbBr3 Perovskite Nanoparticles. J. Am. Chem. Soc. 2014, 136, 850-853. [CrossRef] [PubMed]

17. Swarnkar, A.; Marshall, A.R.; Sanehira, E.M.; Chernomordik, B.D.; Moore, D.T.; Christians, J.A.; Chakrabarti, T.; Luther, J.M. Quantum dot-induced phase stabilization of $\alpha$-CsPbI3 perovskite for high-efficiency photovoltaics. Science 2016, 7, 92-95. [CrossRef] [PubMed]

18. Zhang, X.L.; Eperon, G.E.; Liu, J.H.; Johansson, E.M.J. Semitranspatent quantum dot solar cell. Nano Energy 2016, 22, 70-78. [CrossRef]

19. Zhang, X.L.; Hägglund, C.; Johansson, E.M.J. Highly efficient, transparent and stable semitransparent colloidal quantum dot solar cells: A combined numerical modeling and experimental approach. Energy Environ. Sci. 2017, 10, 216-224. [CrossRef]

20. Zhang, X.L.; Hägglund, C.; Johansson, M.B.; Sveinbjörnsson, K.; Johansson, E.M.J. Fine Tuned Nanolayered Metal/Metal Oxide Electrode for Semitransparent Colloidal Quantum Dot Solar Cells. Adv. Funct. Mater. 2016, 26, 1921-1929. [CrossRef]

21. Chen, L.C.; Tseng, Z.L.; Chen, S.Y.; Yang, S.Y. An ultrasonic synthesis method for high-luminance perovskite quantum dots. Ceram. Int. 2017, 43, 16032-16035. [CrossRef]

22. You, J.; Hong, Z.; Yang, Y.; Chen, Q.; Cai, M.; Song, T.-B.; Chen, C.-C.; Lu, S.; Liu, Y.; Zhou, H.; et al. Low-temperature solution-processed perovskite solar cells with high efficiency and flexibility. ACS Nano 2014, 8, 1674-1680. [CrossRef] [PubMed]

23. Seo, J.; Park, S.; Kim, Y.C.; Jeon, N.J.; Noh, J.H.; Yoon, S.C.; Seok, S.I. Benefits of very thin PCBM and LiF layers for solution-processed P-I-N perovskite solar cells. Energy Environ. Sci. 2014, 7, 2642-2646. [CrossRef]

24. Xing, G.C.; Wu, B.; Wu, X.Y.; Li, M.J.; Du, B.; Wei, Q.; Guo, J.; Yeow, E.K.L.; Sum, T.C.; Huang, W. Transcending the slow bimolecular recombination in lead-halide perovskites for electroluminescence. Nat. Commun. 2017, 8, 1-9. [CrossRef] [PubMed]

25. Xing, G.C.; Mathews, N.; Lim, S.S.; Yantara, N.; Liu, X.F.; Sabba, D.; Grätzel, M.; Mhaisalkar, S.; Sum, T.C. Low-temperature solution-precessed wavelength-tunable perovskites for lasing. Nat. Mater. 2014, 13, 476-480. [CrossRef] [PubMed]

26. Sutherland, B.R.; Hoogland, S.; Adachi, M.M.; Wong, C.T.O.; Sargent, E.H. Conformal Organohalide Perovskites Enable Lasing on Spherical Resonators. ACS Nano 2014, 8, 10947-10952. [CrossRef] [PubMed]

27. Xing, G.C.; Kumar, M.H.; Chong, W.K.; Liu, X.F.; Cai, Y.; Ding, H.; Asta, M.; Grätzel, M.; Mhaisalkar, S.; Mathews, N.; Sum, T.C. Solution-Processed Tin-Based Perovskite for Near-Infrared Laser. Adv. Mater. 2016, 28, 8191-8196. [CrossRef] [PubMed]

28. Kojima, A.; Ikegami, M.; Teshima, K.; Miyasaka, T. Highly Luminescent Lead Bromide Perovskite Nanoparticles Synthesized with Porous Alumina Media. Chem. Lett. 2012, 41, 397-399. [CrossRef]

(C) 2018 by the authors. Licensee MDPI, Basel, Switzerland. This article is an open access article distributed under the terms and conditions of the Creative Commons Attribution (CC BY) license (http://creativecommons.org/licenses/by/4.0/). 